\title{
特集の消化性潰瘍
}

\section{Nピyクス 消化性潰瘍：診断と治療の進歩}

\section{I. 診断ट病態 \\ 4. 内視鏡診断と経過観察}

小黒八七郎*

\begin{abstract}
要 旨
消化性潰瑒の診断では，特に胃潰瘍と胃癌との鑑別診断が重要であり，内視鏡，色素法と生 検によって速やかに確診が得られ，前方視鏡により十二指腸潰瘍の性状の診断る容易である。 胃潰瘍の経過で，まず，時相と治癒判定について述べる，癌化は過去に唱えられたほど高頻度 ではないが, 少頻度に認められており, 慢性胃潰瘍では生検による経過追跡が必要である。潰 瘍の再発抑制と $\mathrm{H}_{2}$ ブロッカー投与期間が問題となっている。【日内会誌 $80: 22 \sim 26,1991$ 〕
\end{abstract}

\section{1. 消化性潰瘍の内視鏡診断}

\section{1）上部消化管内視鏡の進歩}

内視鏡の性能の向上と普及につれて,世界的に, X線検查に代わって上部消化管内視鏡検查は細径 前方視鏡で行われ，日本でもかかる赹勢となって いる.その理由は，細径前方視鏡ではX線検査と同 様に食道から十二指腸に至る全上部消化管の検査 が可能であり, 内視鏡検査の苦痛の軽減と偶発症 の激減，X楾検査より楽という患者の増加，内視鏡 検查の確実性, 随時生検が可能のため初回検査で 最終診断が得られることなどのためである（表 1 ).

\section{2）胃潰瘍診断の思考過程}

間接X線写真読影時には, 存在診断, 質的診断そ して量的診断の順の考方方で行われており，内視 鏡診断の場合にはこれらは同時に行われることが 多いが，思考順序として有意義である。存在脍断 とは, 病変の有無の診断であって, X楾でも胃の潰 瘍性病変のニッシェや変形像などによって, 潰瘍 およびその症痕を含む胃癌などの存在診断はかな り可能であるが，内視鏡による生検では存在診断 と同時に質的診断が可能になる，質的診断とは，

\footnotetext{
*扰ぐろやな拉，国立がんセンタ一
}

発見された胃潰湯性病变が良性か否かを鑑別する ことをいう、マクロレベルの診断の場合には，い わゆる悪性指標があることが前提となる，内視鏡 検査では適正な条件下での観察と読影，さらには 色素散布と生娭を行う。癌は発生初期にさかのほ る程，肉眼レベルに打ける悪性所見に乏しくなる ため，マクロレベルの診断では質的診断はもとよ り存在䛦断も困難になる。生検は一般には，肉眼 レベルで変化が認められる病巣に対して, 癌であ ることを追認するために行われることが多いが， わずかな変化を目標として粗撃生検を行って胃癌 と鑑別する．量的診断とは，発見された病変の程 度に関する診断である。胃潰演では，そのstage分 類や深さ, 穿孔の有無, 形態, 難治度の判断など である。

\section{3）胃潰瘍性病変の5段階診断}

胃潰瘍と潰瘍を含む胃癌の鑑別診断は日常, 極 めて重要である.市川はX線診断において, 診断が 比較的容易な進行胃癌から極めて困難な早期胃癌 に至る 5 段階鑑別診断の考方方を提唱した。その 主旨は先ずBorrmann 2または 3 型進行胃癌を良 性潰瘍から鑑別して除外し，漸次早期胃癌 IIC+ III, III+IIc，IIIを鑑別除外してゆき，最後に良性 の胃潰瘍之診断する考方方である，最初は容易で あるが，段階が進むにつれて優れた写真の撮影と 慎重な読影が要求される。良性の胃潰瘍は胃癌や 
表 1.上部消化管検查に扣けるX線上内視鏡の対比

\begin{tabular}{|c|c|c|}
\hline & 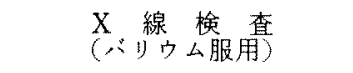 & 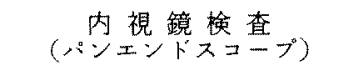 \\
\hline 前処置 $\left\{\begin{array}{l}\text { 遮断薬注 } \\
\text { 咽頭麻酔 }\end{array}\right.$ & $\begin{array}{l}\text { 時に副作用，偶発症 } \\
\text { 使用せず }\end{array}$ & $\begin{array}{c}\text { 同 左 } \\
\text { 稀にキンロカイン・ショック }\end{array}$ \\
\hline 娭查後便秘 & 人によりきわめて強い & 関係なし \\
\hline $\mathrm{X}$ 線 被 曝 & あ & な \\
\hline 技師 の検 查 & 可（たたし，医師の監督下） & 不 可 \\
\hline 年間集団検骖数 & 約 500 万人 & X線仼ど多くない \\
\hline 検 查 時苦 痛 & 少 い(個人差あり) & かなりあり（個人差大） \\
\hline 診 䉼 精 度 & 可 一 僈 & 霓 一 秀 \\
\hline 生 検 組 織 䛦 & 不能 & 可 能 \\
\hline 全体像 & 秀 & 良 \\
\hline 周辺之の関連 & 秀 & 可 \\
\hline 湘 & 秀 & 良 \\
\hline 潰演 の 深 さ & 秀 & 良 \\
\hline 穿孔の有 無 & 秀 & 可 \\
\hline 徽 細 観 察 & 優 & 秀 \\
\hline 出 血 源 診 断 & 可 & 秀 \\
\hline 重症者の検査 & 不 & 能 \\
\hline 運 & 困 & 容易 \\
\hline 価 敕（設 備） & 高 & はるかに安価 \\
\hline
\end{tabular}

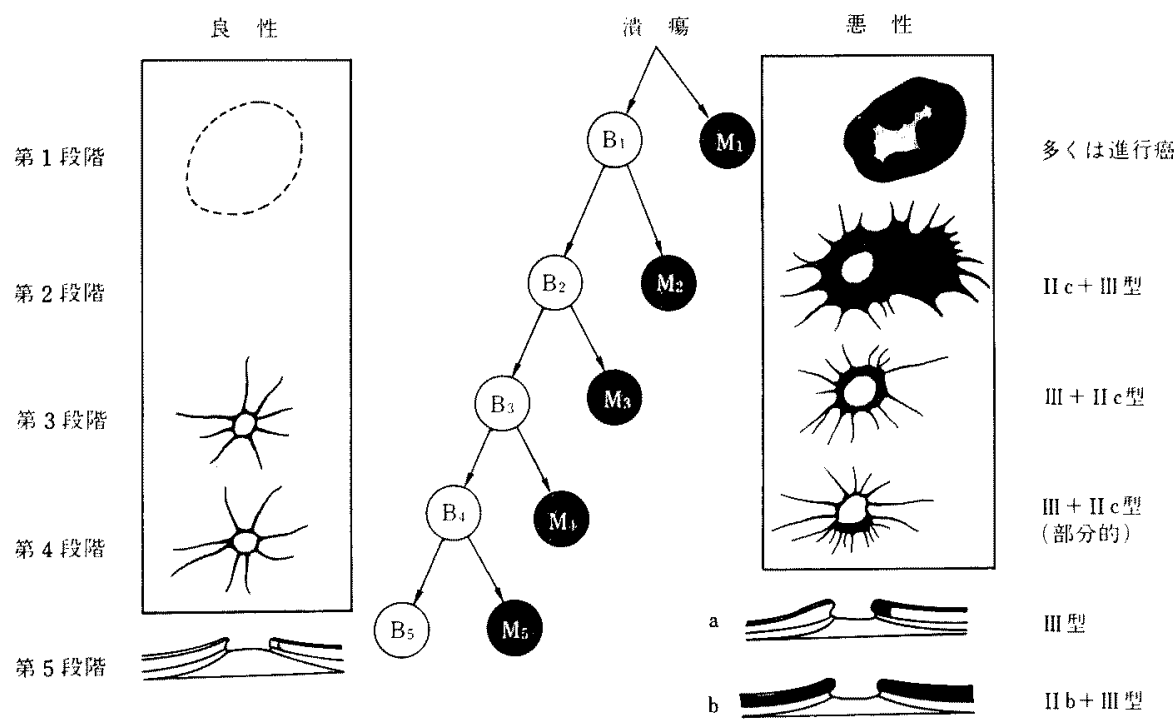

図 1，胃潰瘍の良性・悪性の鑑别に抢ける5段階（X線括よび内視鏡所見）(最b濃い 部分は癌組織)

胃肉腫を除外診断して始めて可能であり，悪性病 変を見逃してはならないという慎重な考学方に基 ふいており，かかる考え方は内視鏡診断にも有用 である(図 $1^{1)}$ ).

\section{4）色素内視鏡と胃生検}

色素内視鏡はコントラストの明瞭化により，敏 細病変の存在診断と判り難い性状の病変の補助診 断として有効であり，最終的には生検で確診を行 
5.色素内視鏡にはインジゴルミンが簡便で有 効であり，最も広く行われている，われわれの成 績2)によると，内視鏡で良性胃漬瘍玉たはとの疑 いとした病変に対して行った生検の中から,7.6\% の癌陽性率が得られ, 同じく潰瘍症痕様の病変か らは2.4\%で, 内視鏡肉眼診断の限界を意味してい る。

\section{5）胃潰瘍の深さと形態の診断}

村上（忠重）の漬瘍の深さ(UI)の分類は病理 組織学的分類で, UI-IIからUI-IVまでが胃潰瘍で あり, UI-IIは粘膜筇板の断裂, UI-IIIはさらに固有 等層の一部の断裂, UI-IVは固有筋層の全層の断 裂で穿孔も含まれる。活動期潰瘍の深さはX線，内 視鏡検查でかなり可能であるが，修復期と痗痕期 では胃壁欠損の深さとUIの程度とは一致しない ので難しい. 近年, 超音波内視鏡の性能の向上に より, UIの程度の診断はかなり可能となってきて いる.

再生粘膜と繊維化が不均等に括きると修復期以 降の潰瘍の形は不整となり，潰瘍型胃癌との鑑別

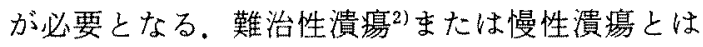
外来内科的治療に抗して 3 力月以上未治癒のもの を呼び，概して難治性である。難治性のため手術 された胃潰湟の多くはUI-IVであり，線状潰瘍む 多い, 従来, 初発潰瘍の約 $30 \%$ は難治性漬瘍に移 行するとされていたが，最近の薬物療法の進歩に よってその率は低くなってきている。

\section{6) 十二指腸潰瘍の内視鏡診断 ${ }^{21}$}

十二指腸潰瘍は球部前壁之球底部に好発し，内 視鏡では容易に観察できる。十二指腸潰瘍が慢性 化すると瀻維增殖による収縮により，X線ではク ローバ状変形とタッシェを呈し，内視鏡ではridge formation（分水嶺形成）とpocketが認められる (図 2). 十二指腸潰癔の時相之深さは胃潰瘍に準 じて行われている.十二指腸潰瘍では潰瘍周辺に しばしば「しもふり」肉に和けるような多数の白 色点が観察されるが，これは十二指腸のびらんで ある，十二指腸には癌はまれであるが，早期十二 指腸癌が発見されれば症例報告に値する。

7）胃潰瘍・疫痕と潰瘍型胃癌の鑑別診断

X線と内視鏡の肉眼レベルに扣ける胃潰瘍と潰

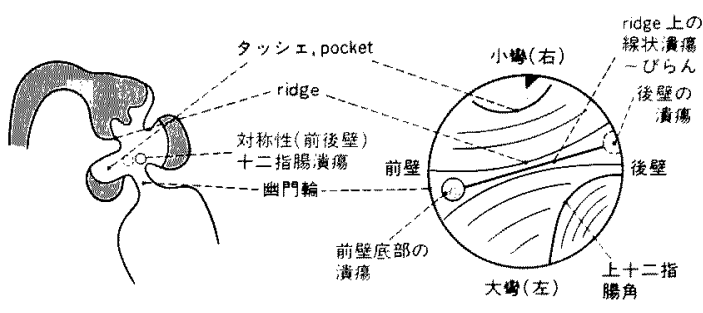

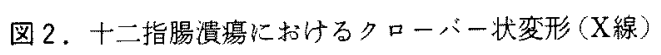
¿ridge formation (内視鏡) の対比

$\mathrm{U1}(+)$, 早期照癌

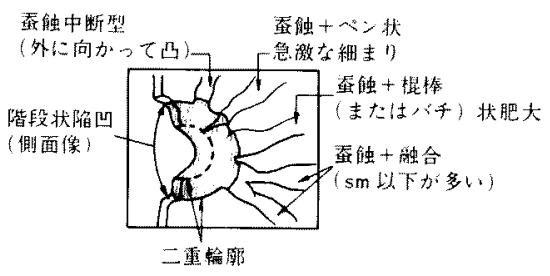

図 3.集中粘膜ひだ末端の悪性（癌）像（網点の部分 は癌組織)

瘍型胃癌の鑑別診断は概して活動期においては難 しい.その理由はIIIやIII+IIc型早期胃癌において は悪性所見が認め難いことによる，再発胃潰㻛で は活動期に和いても粘膜ひだの集中を伴い，初発 漬瘍の活動期では認められないことが多いので, 初発と再発潰瘍の鑑別の手がかりの重要所見とな るが，修復期と瘵痕期においては参考にはならな い. 良悪性の鑑別䛦断にはそれらの求心側末端に 扣ける悪性所見の有無をよく精查し，そこの生検 で癌の有無を確認する。図 $3^{21}$ は虫蝕像を主とす る悪性（癌）の所見で多くは早期胃癌である。粘 膜ひだの末端の融合あると sm以下の癌浸潤があ るとされて括り，融合が進み環状の周堤を形成す れば進行胃癌である3. 癌浸潤が潰瘍周辺の粘膜 下浸潤が主な場合には㫤蝕像が認められなくなる ので注意を要する。

(1) open ulcerとIIIを含む早期胃癌との鑑別 診断

IIIはopen ulecrに相当しその周辺に肉眼レベル では認知し難いIIbが有る場合で，钽密にはIII+ IIbとするべきである.癌組織と共存する消化性潰 瘍との位置関係から筆者 ${ }^{2}$ は全周型, 偏在型, 両極 


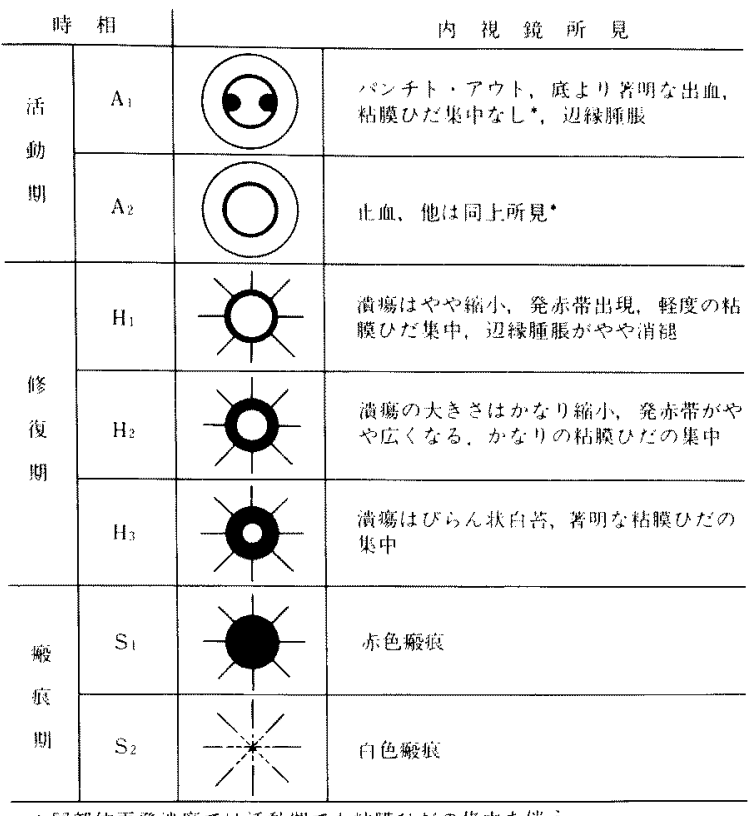

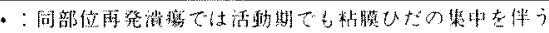

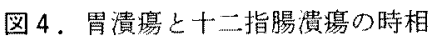

型と微小癌型とに分けている．純粋のIII と消化性 漬瘍との鑑別診断は至難であり，生検でも癌組織 に的中しなければ為陰性となる，施設によって III の頻度にはかなりのばらつきがあるが，Ibに拈け ると同様にIIIの判定基準が施設によって相違があ るためと考えられる．IIc+III季たはIII+IIcでは IIC部分が比較的目立つので診断上問題が少ない。

\section{（2）胃潰瘍疫痕とIIcの鑑別診断}

IIcの $90 \%$ はI（十）であり，胃潰瘍疫痕との鑑 別が問題となる。ここでは, UI (十)・IIcとは基本 型のIIc・UI $(+), \quad \mathrm{UI}(+)$ の混合型のIIc + IIb と $\mathrm{IIb}+\mathrm{II}$ の総称とする. UI $(+) \cdot I I c は X$ 線や内視 鏡の肉眼レベルでは多くは粘膜ひだの集中を伴っ て観察される。多くの場合, 粘膜面においては癌 組織は原発宩を中心として遠心性に広がってゆ く、癌組織により侵食された粘膜ひたは性状粘膜 よりる僅かに陥凹して抢り，丁度，㝠が蝕んだよ らな所見を呈しているため，軖蝕と呼ばれている. 虫蝕により集中する粘膜ひだが不連続になった り，陷凹する場合にはそれぞれ中断または断裂， 階段状陥凹と呼ばれている(図 $\left.3^{2}\right)$. 荲蝕された 粘膜ひだの断端は内部に向かって凹となり，これ をconcavityと呼んでいる。それに対して，良性潰 瘍またはその症痕に伴ら集中する粘膜の中断は内 部に向かって凸であり，これをconvexityと呼ん でいる3).

\section{2. 消化性潰瘍の経過}

\section{1）胃潰瘍の時相と治癒判定の診断 ${ }^{2)}$}

胃潰瘍の時相は胃壁の急激な欠損と出血を伴 活動期 (A) に始まり，その欠損部には次第に毛細 血管が增生して繊維化して欠損部は修復されてゆ く修復期 $(\mathrm{H})$ となり，一方その表面は再生粘膜で 被われて瘦痕期(S) に至る。これを胃潰瘍のAHS 時相分類（㠃田の分類）と呼ぶ。胃潰瘍の時相に ついては図4のよ5に, 活動期は $\mathrm{A}_{1}$ 之 $\mathrm{A}_{2}$, 修復期 は $\mathrm{H}_{1}$ と $\mathrm{H}_{2}$ に分けられ， $\mathrm{H}_{2}$ の後期では潰瘍欠損は ほとんど修復され，その粘膜表面にしぱしばびら ん状の薄い白苔が付着して和り，この状態を $\mathrm{H}_{3}$ と 呼ぶことがある， $\mathrm{H}_{3}$ ではX線や病理では洀痕治癒 と判定されることが多い，洀痕期は $\mathrm{S}_{1}$ (赤色痗痕) と $\mathrm{S}_{2}$ (白色疲痕) とに分けられる。潰瘍欠損部が 完全に修復されその表面の白苔が消失して再生粘 膜で被われた時点 $\left(\mathrm{H}_{3} \rightarrow \mathrm{S}_{1}\right.$ 時点 $)$ を治㮩と判定す るとの意見が主流である。

2）胃潰瘍の再発・再燃と良性・悪性サイクル 胃潰瘍症痕から再び潰瘍化すれば再発と呼び, 未治癒潰瘍の欠損部が増大すれば再然と呼ぶ. 前 回潰瘍之再発潰瘍の位置関係から, 同部位, 近傍, 他部位再発とに分けられている。潰瑝治瘾後の再 発率は 1 年後に打いておよを $20 \%$ に認められてお り，いかにしてこの再発を抑制するか，そして潰 瘍治瘉後, $\mathrm{H}_{2}$ ブロッカーを何時をで投与するかが 問題となっている.

胃潰瑒が $\mathrm{A} \rightarrow \mathrm{H} \rightarrow \mathrm{S} \rightarrow \mathrm{A}$ の経過をたどることを 良性サイクルと呼び，IIbまたはIIc型の早期胃癌 病巣内に消化性漬瘍が同様の経過をたどることを 悪性サイクル2゙呼び，これを繰り返しながら進 行胃癌に移行する，悪性サイクルの際の潰瘍性病 変の性状, 経過, 胃液酸度や組織像なとは良性の 消化性潰瑒のそれらと良く似ているため, paptic ulcerationと見なされ，消化性潰瘍を含む多くの 
早期胃癌に認められる4)，悪性サイクルという名 称は1966年，村上 (忠重)によって提唱された。

\section{3）慢性胃潰瘄と胃潰瘍瘶痕の癌化}

Hauserは慢性胃潰瘍の边縁には常に刺激が作 用して癌化を促すといら癌発生説を唱え, 慢性胃 潰瘍が癌化したと見なされるHauserの基準を設 定した。これは，断裂した固有等層が粘膜筋板と 癒合し, 癌組織は潰癔辺縁のみに存在し潰瘍底に はみられないものである。この基準に合致すれば 慢性胃潰瘍が癌化したものとみなし潰瘍癌と呼ん だ.Hauserの潰瘍癌の中の潰瘍は村上の胃潰瘍の 深さの分類のUI-IVに相当しており，この潰瘍癌 はUI·IVを共存するIII型またはIII +IIc型早期胃癌 に相当している. Hauserの説は日本の病理・外科 学者によって压倒的に支持され，高率な胃潰湯の 癌化率が報告され，わが国では，1970年代に至る まで, 癌化の予防といら名分で胃潰瘍の手術は盛 んに行われた。佐野 ${ }^{3}$ は「良性胃潰瘍が癌化したる のか，または粘膜内癌が先に存在し，それに二次 的な消化性漬晹が合併したものか， ulcer typeの 早期癌における，いわゆるulcer cancer (Ulkuskarzinom）の病理学的解決は困難である」と述べ ている。

胃潰瘍の癌化を内視鏡的に検討する方法には逆 追跡法之前向き追跡法の二つの方法がある21. 前 者は発見された胃癌の以前の内視鏡像を追跡する 方法で，胃癌の初期像を知ることができる。この 方法によって，胃癌の各型のnatural historyはか なり解明され，胃癌の初期像の多くは慢性胃炎様 所見と胃潰瘍症痕様所見が得られていた。後者は 生検で良性と確認された病変を生検により定期的 に長期間追跡する方法で, 生検癌陽転例に遭遇す ることはあまり経験されなかったため，胃潰瘍の 癌化説は否定的となった。しかし，われわれの成 績 ${ }^{2)}$ によれば， 2 年以上生検で追跡したopenの慢 性胃潰瘍中, $2.7 \%$ に生検陽転認め, 確実に癌化 とみなされ，この方法によって，僅かな頻度では あるが，慢性胃潰癔の癌化があることが証明され た。
第51回胃癌研究会5)における発表によると, UIIVを伴う早期胃癌, すなわち, Hauser型胃癌は癌 单に二次的に消化性潰瘍が生じたものとし癌先行 説に肯定的な内容が多く，充た，慢性胃潰瘍を生 検で追跡した結果，潰瘍の癌化を肯定できる例は 少なかった，潰瘍を含む胃癌の発生については， 胃癌の先行之慢性胃潰瘍の癌化の二つの過程があ ると考えられる。

近年, openの胃潰瘍からよりも, 胃潰瘍洀痕か らの癌の発生がより多いと考えられている. 1988 年 6 月に行われた第51回胃癌研究会5に批いて, 末広らは1985年を境として，症痕癌が $0.9 \%$ から $9.0 \%$ となり，増加する傾向があると発表してい

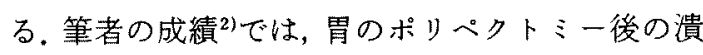
演㭚痕はUI-IIが多く，粘膜ひだの集中は 1 力月前 後で消失することが多い。このうにUI-IIに伴う 粘膜ひだの集中は消失することがあるため, UI-II の潰瘍洀痕と通常の胃炎像との鑑別診断は不可能 となる：したがって，胃癌の発生は慢性胃炎を母 地とするのか，胃漬瘍症痕を母地とするのかの議 論は無意味となる。慢性胃炎か胃漬瘍㾝痕のいず れから胃癌が発生するかといら議論は無意味とな る.

内視鏡と生検による胃潰助癌化説の大幅な後退 と $\mathrm{H}_{2}$ ブロッカーの開発と普及により胃潰瘍の多 くは内科的治療の対象となって扣り, 大出血, 穿 孔や難治性潰瘍などの特殊な場合にのみ胃漬瘍手 術が行われ，急減している。

\section{文 献}

1）市川平三郎，小黒八七郎：消化性潰愓の鑑別猃断. 日本医師会雑誌 $90: 2712,1983$.

2) 小黑八七郎：胃癌と内視鏡険查（改版）. 羊土社, 1984.

3）佐野量造：胃疾患の肉眼病理。医学書院, 1974.

4）吉田茂昭, 小黑八七郎, 他: 陷凹性早期胃癌に合 併する潰瘍の深さ上 Malignant cycle について。 Prog Dig Endosc 8: 96, 1976.

5) 主題 II : Hauser 型胃癌の抁大解釈とその周辺: 第 51 回胃癌研究会 (1988 年 6 月). 日癌治誌 24 : $1335,1989$. 